\title{
Ülseratif kolit hastalarında nötrofil lenfosit oranı ve platelet lenfosit oranı, klinik ve endoskopik aktivite indeksleri ile ilişkili midir?
}

\author{
Do the neutrophil-lymphocyte ratio and platelet-lymphocyte ratio correlate with clinical and \\ endoscopic activity indices in ulcerative colitis patients?
}

\section{(D) Serkan YALAKI ${ }^{1}$, (D) Mehmet Suat YALÇIN² , (D) Hüseyin PULAT ${ }^{3}$, (D) Aysu ILHAN ${ }^{4}$}

Mersin Eğitim ve Araştırma Hastanesi, ${ }^{1}$ Gastroenteroloji Kliniği, ${ }^{3}$ Genel Cerrahi Kliniği, ${ }^{4}$ Çocuk Hastalıklanı Kliniği, Mersin, Içel Aksaray Eğitim ve Araştırma Hastanesi, ${ }^{2}$ Gastroenteroloji Kliniği, Aksaray

Giriş ve Amaç: Ülseratif kolitin hastalık aktivitesine ve ciddiyetine göre sınıflandırılması klinik uygulamada önemlidir, çünkü hastanın yönetimini belirler. Bu çalışmada, nötrofil lenfosit oranlarn ve platelet lenfosit oranlarının, ülseratif kolit hastalarında klinik aktivite indeksinin yanı sira mukozal hastalığa göre hastalık şiddetini belirleyen endoskopik aktivite indeksleri ile olan ilisskilerinin ortaya konulması amaçlanmıștır. Gerec ve Yöntem: Calışma tek merkezli, vaka kontrollü bir çalışma olarak planlandı. Yeni tanı almış 99 ülseratif kolit'li hastadan klinik aktivite indekslerine ve endoskopik aktivite indekslerine göre aktif hastalık ve remisyon grupları oluşturuldu. Kontrol grubu 56 sağlıklı bireyden oluşturuldu. Bulgular: Klinik aktivite indekslerine göre gruplar arasında nötrofil lenfosit oranı ve platelet lenfosit oranı istatistiksel olarak farklı saptandı $(p<0.01)$. Nötrofil lenfosit oranı ve platelet lenfosit oranı için kesme değerleri sirasıla 2.10 (\%90 sensitivite, $\% 45$ spesifite) ve 152.13 (\%70 sensitivite, \%33 spesifite) olarak saptand1. Endoskopik aktivite indekslerine göre gruplar arasında nötrofil lenfosit oran ve platelet lenfosit oranı istatistiksel olarak farklı saptand $(p<0.01)$. Nötrofi lenfosit oranı ve platelet lenfosit oranı için kesme değerleri sırasıyla 2.09 (\%97 sensitivite, \%39 spesifite) ve 151.72 (\%73 sensitivite, \%31 spesifite) olarak saptandı. Sonuç: Calışmamız; aktif ülseratif kolit hastalarında nötrofil lenfosit oranı ve platelet lenfosit oranı seviyelerinin anlamlı şekilde arttığın ve bunun klinik, endoskopik ve laboratuvar endeksleri ile korele olduğunu göstermiştir. Bu inflamatuvar belirteçler tek başına ya da birlikte hastalık aktivitesini tahmin edebilir

Anahtar kelimeler: Ülseratif kolit, nötrofil lenfosit oranı, platelet lenfosit oranı, endoskopik aktivite indeksi, klinik aktivite indeksi

\section{GİRIŞs}

Inflamatuvar barsak hastalı̆ı̆ını bir türü olan ülseratif kolit (ÜK), gastrointestinal sistemin kronik, idiyopatik ve tekrarlayan inflamatuvar bir durumudur. Bu inflamasyon; sıklıkla rektumdan başlayıp, sürekli olarak ileumun son kısmına kadar uzanabilen, kolonun mukozasında sınırlı, diffüz, spesifik olmayan bir inflamasyondur. Tipik olarak, ÜK'li hastalarda nüks ve remisyon dönemleri görülür. Ilk ataktan sonra \%90’a kadar bir veya daha fazla nüks olacaktır ve ilk 2 ylldaki erken relaps veya aktif hastalık, daha sonra daha kötü bir hastalık seyri ile ilişkilidir (1).

Yalaki S, Yalçın MS, Pulat $H$, et al. Do the neutrophil-lymphocyte ratio and platelet-lymphocyte ratio correlate with clinical and endoscopic activity indices in ulcerative colitis patients? Endoscopy Gastrointestinal 2020;28:5-11.
Background and Aims: Classification of ulcerative colitis according to disease activity and severity is important in clinical practice because it determines the optimal patient management strategy. In this study, we aimed to investigate the relationship of the neutrophil-lymphocyte ratio and platelet-lymphocyte ratio to the clinical activity index in ulcerative colitis patients, as well as endoscopic activity indexes that determine disease severity in mucosal disease. Materials and Methods: The study was planned as a single-center, case-controlled study. Active disease and remission groups were formed from 99 newly diagnosed ulcerative colitis patients according to their clinical activity indexes and endoscopic activity indexes. The control group consisted of 56 healthy subjects. Results: According to the clinical activity index, neutrophil-lymphocyte ratios and platelet-lymphocyte ratios were significantly different between the groups $(p<0.01)$. The cut-off values for neutrophil-lymphocyte ratios and platelet-lymphocyte ratios were 2.10 (90\% sensitivity, 45\% specificity) and 152.13 (70\% sensitivity, 33\% specificity), respectively. According to the endoscopic activity index, neutrophil-lymphocyte ratios and platelet-lymphocyte ratios were statistically different between the groups $(p<0.01)$. The cut-off values for neutrophil-lymphocyte ratios and platelet-lymphocyte ratios were 2.09 (97\% sensitivity, $39 \%$ specificity) and 151.72 (73\% sensitivity, 31\% specificity), respectively. Conclusion: Our study showed that neutrophil-lymphocyte ratios and platelet-lymphocyte ratio levels were significantly increased in active ulcerative colitis patients and correlated with clinical, endoscopic, and laboratory indices. These inflammation markers, alone or in combination, can predict disease activity.

Keywords: Ulcerative colitis, neutrophil-lymphocyte ratio, platelet-lymphocyte ratio, endoscopic activity index, clinical activity index

ÜK'in hastalık aktivitesine ve ciddiyetine göre sinıflandırılması klinik uygulamada önemlidir, çünkü hastanın yönetimini belirler. Hastalık aktivitesinin erken belirlenmesi, ciddi ÜK hastalarında cerrahi oranı ve mortaliteyi azaltır (2). Klinik pratikte, hastalığın aktivitesini belirlemek için klinik, laboratuvar çalışmaları, görüntüleme testleri ve histopatoloji dahil endoskopik parametrelerin kombinasyonu kullanılmaktadır. Laboratuvar parametreleri olarak; C-reaktif protein (CRP), eritrosit sedimantasyon hızı (ESR), beyaz kan hücreleri (WBC), fekal kalprotektin, ÜK'teki hastalık aktivitesini yan-

İletişim: Serkan YALAKI Mersin Eğitim ve Araştırma Hastanesi, Gastroenteroloji Kliniği, Korukent Mah. 96015 Sok. Mersin Entegre Sağlık Kampüsü, 33240 Toroslar/Mersin• Tel: +90 3242251000 •E-mail: serkanyalaki@hotmail.com Geliş Tarihi: 14.11.2019 Kabul Tarihi: 19.04.2020 
sitmakta yaygın olarak kullanılmaktadır $(3,4)$. Ancak, bunların hiçbiri ideal bir belirteç olarak tanımlanmamıştır. İdeal bir belirteç hızlı, kolay ve test edilmesi ucuz olmalı ve belirli bir hastalığa yatkın bireyleri tanımlayabilmelidir. Belirteç, hastalık aktivitesini tanımlayabilmeli ve tedavinin etkinliğini belirtmelidir. Ne yazık ki, böyle bir belirteç henüz mevcut değildir (5). Çeşitli inflamatuvar ve neoplastik hastalıklarla ilişkilendirilen basit, ucuz ve etkili bir inflamasyon belirteci, nötrofil lenfosit oranı (NLR) ve platelet lenfosit (PLR) oranıdır (6-8). Nispeten daha yeni olan bu inflamatuvar belirteçlerin, aktif ÜK hastalarında arttığı iyi bilinmektedir $(8,9)$. Bununla birlikte, endoskopik aktif hastalığın tanımlanmasındaki NLR ve PLR dahil olmak üzere bazı inflamasyon belirteçlerinin duyarlılığı ve mukozal yaralanma ile korelasyonu azdır. Bu çalışmada, yeni olan bu inflamasyon belirteçlerinin (NLR ve PLR) ÜK hastalarında klinik aktivite indeksinin (KAI) yanı sıra mukozal hastalığa göre hastalık şiddetini belirleyen endoskopik aktivite indeksleri (EAI) ile olan ilişkilerini araştırmayı amaçladık.

\section{GEREÇ ve YÖNTEM}

\section{Hasta Seçimi}

Çalışma tek merkezli, vaka kontrollü bir çalışma olarak planlandı. Bölge Hastanesi Gastroenteroloji polikliniklerine, Ağustos 2017 ile Ekim 2019 tarihleri arasında başvuran, yeni tanı almış, yetişkin ÜK'li hastalar çalışmaya dahil edildi. ÜK tanısı; klinik, laboratuvar, kolonoskopik ve patolojik inceleme sonucu gastroenteroloji uzmanlarinca konuldu. Bu süreç içerisinde tanı konulmuş 99 ÜK'li hastadan çalışma grubu oluşturuldu.

Sağlıklı popülasyondan çeşitli endikasyonlar nedeniyle kolonoskopisi yapılan ve kolonoskopi raporları normal olan, yaş ve cinsiyet uyumlu, 56 sağlıklı birey kontrol grubu olarak çalışmaya dahil edildi. Malignite öyküsü olanlar, son 6 ay içerisinde cerrahi geçirmiş olanlar, göğüs röntgeni, idrar örneği analizi ve dışkı testi ile tespit edilebilen aktif enfeksiyonlu hastalar ve/veya sağlıklı bireyler çalışma dışı bırakıldı.

\section{Endoskopik Prosedür}

Gastroenteroloji Bölümümüz endoskopi ünitesinde deneyimli gastroenteroloji uzmanları ile endoskopik işlemler yapıldı. Uygun diyet eşliğinde sodyum fosfat ile optimal bağırsak hazırlığının ardından, her kolonoskopik işlem için bir kolonoskop (EVIS LUCERA ELITE CLV-290SL; Olympus Medical Systems, Tokyo, Japonya) kullanıldı. Her hastanın başvuru anındaki kolonoskopi raporları esas alındı.

Değerlendirilmeye alınan ÜK hastalarının anatomik yaygınlığının belirtilmesinde Montreal sinıflaması kullanıldı (10). Bu sinıflamada hastalık yaygınlığı E1: proktit, E2: sol kolon tutulumu, E3: yaygın kolit şeklinde kategorize edildi.
ÜK'li hastaların endoskopik bulgularına göre aktivite indeksleri, ünitemizde rutin olarak Modifiye Baron EAI kullanıldığından bu yöntemle değerlendirildi. Bu endoskopi tabanlı skorlama sisteminde dört sinıf vardır; normal mukoza [0], anormal vasküler paternli granüler mukoza [1], gevrek mukoza [2], kendiliğinden kanama ile mikroülserasyon [3] ve gross ülserasyon [4]. Sinif 0 ve 1 remisyon, sinif 2, 3 ve 4 aktif hastalık olarak değerlendirildi (11).

\section{Klinik ve Laboratuvar}

ÜK hastalarındaki hastalık aktivitesi Truelove ve Witts kriterleri ile değerlendirildi (12). Bu kriterler ÜK'li hastaların basit ve hızlı bir şekilde sınıflandırılmasını sağlar. Bu sınıflandırmayı kullanarak ÜK hastaları; günlük kanlı dışkı sayıları, kalp atım hızı, hemoglobin, ESR ve vücut sıcaklığına bağlı olarak hafif, orta veya ağır olarak sınıflandırıldı. Orta ve şiddetli hastalık sınıfları aktif hastalık olarak değerlendirildi.

Kolonoskopik muayene gününde incelenen tam kan sayımı dahil tüm laboratuvar bulguları hastaların tıbbi kayıtlarından elde edildi.

\section{İstatistiksel Analiz}

Istatistiksel analiz, SPSS 22.0 istatistik paketi (SPSS, Inc., Chicago, IL, ABD) kullanılarak yapıldı. Veriler ortalama \pm standart sapma olarak ifade edildi. Demografik parametrelerdeki farklılıkları değerlendirmek için Mann Whitney U testi, laboratuvar parametrelerini gruplar arasında karşılaştırmak için Kruskal Wallis testi kullanılmıştır. Parametreler arasındaki korelasyonu analiz etmek için Spearman korelasyonu kullanıldı. Tüm p değerleri iki yönlü idi ve $\mathrm{p}<0.05$ istatistiksel olarak anlamlı kabul edildi. Duyarlılık, özgüllük ve kesme noktaları, bir alıcı işletim karakteristik eğri analizi (ROC) kullanılarak değerlendirildi.

\section{Etik Onam}

Endoskopik incelemeden önce her denekten yazılı onam alındı. Çalışma mevcut etik ilkere uymuş ve Hastanemiz Etik Kurulu tarafından onaylanmıştır.

\section{BULGULAR}

Doksan dokuz ÜK'li hasta ile çalışma grubu, 56 kişi ile kontrol grubu oluşturuldu. Grupların genel karakteristikleri Tablo l'de verilmiştir. Çalışma ve kontrol grubunda yaş ortalaması sirasiyla $42.52 \pm 15.82$ ve $46.25 \pm 14.50$ bulundu. Cinsiyet dağılımı ise gruplar arasında sırasıyla şöyle idi: 60 erkek (\%60.6), 39 kadın (\%39.6); 32 erkek (\%57.1), 24 kadın (\%42.9). Gruplar arasında yaş ve cinsiyet dağılımı açısından fark yoktu ( $\mathrm{p}=0.09$ ve $\mathrm{p}=0.67 ; \mathrm{p}>0.05)$.

ÜK'li hastaların anatomik dağılımına bakıldığında; El: 34 vaka (\%33.66), E2: 28 vaka (\%27.72), E3: 37 vaka (\%36.63) 
Tablo 1. Grupların genel özellikleri

\begin{tabular}{|c|c|c|c|}
\hline Değişken & Kontrol Grubu & Çalışma Grubu & $\mathbf{p}$ \\
\hline Yaş & $46.25 \pm 14.50$ & $42.52 \pm 15.82$ & 0.09 \\
\hline Cinsiyet, n (\%) & $\begin{array}{l}32 \text { erkek (\%57.1) } \\
24 \text { kadın (\%42.9) }\end{array}$ & $\begin{array}{l}60 \text { erkek (\%60.6) } \\
39 \text { kadın }(\% 39.6)\end{array}$ & 0.67 \\
\hline Anatomik dağılım, n (\%) & & $\begin{array}{l}\text { E1: } 34(\% 33.66) \\
\text { E2: } 28(\% 27.72) \\
\text { E3: } 37(\% 36.63)\end{array}$ & \\
\hline EAİ, n (\%) & Normal & $\begin{array}{l}\text { Aktif hastalık } 72(\% 72.7) \\
\text { Remisyon } 27 \text { (\%27.3) }\end{array}$ & \\
\hline KAI, n (\%) & Normal & $\begin{array}{l}\text { Aktif hastalık } 63 \text { (\%63.6) } \\
\text { Remisyon } 36 \text { (\%36.4) }\end{array}$ & \\
\hline Toplam & 56 & 99 & \\
\hline
\end{tabular}

EAI: Endoskopik aktivite indeksi, KAI: Klinik aktivite indeksi.

Tablo 2. KAİ'ine göre inflamasyon belirteçlerinin gruplar arasında karşılaştırılması

\begin{tabular}{lcccc} 
Değişkenler & Çalışma Grubu & Inaktif Hastalık & Aktif Hastalık & p \\
\hline WBC & $7277.86 \pm 1717.22$ & $8320 \pm 2267.13$ & $9664.76 \pm 3544.65$ & $<001$ \\
\hline ESR & $4.89 \pm 2.27$ & $20.20 \pm 14.88$ & $27.89 \pm 18.21$ & $<0.01$ \\
CRP & $4.47 \pm 2.48$ & $9.91 \pm 8.12$ & $42.93 \pm 42.77$ & $<0.01$ \\
NLR & $2.26 \pm 1.75$ & $3.18 \pm 2.10$ & $4.94 \pm 4.24$ & $<0.01$ \\
PLR & $124.98 \pm 53.53$ & $183.95 \pm 88.00$ & $225.79 \pm 151.73$ & $<0.01$
\end{tabular}

KAI : Klinik aktivite indeksi, WBC: Lökosit sayısı, ESR: Eritrosit sedimantasyon hızı, CRP: C reaktif protein, NLR: Nötrofil lenfosit oranı, PLR: Platelet lenfosit oranı.

saptandı. EAI'lerine göre remisyonda olan 27 vaka (\%27.3), aktif hastalığı olan 72 vaka (\%72.7) saptandı. KAI'lerine göre hastaların dağılımı şöyleydi; remisyonda olan 36 hasta (\%36.4), aktif hastalığı olan 63 vaka (\%63.6).

Hastalık klinik aktivite grupları arasındaki inflamasyon belirteçlerinin karşılaştırılması Tablo 2'de verilmiştir. Aktif gruptaki ortalama WBC, CRP ve ESR değerleri remisyon grubu ve kontrol grubuna göre anlamlı derecede yüksekti $(\mathrm{p}<0.01)$. Aktif hastalarda serum nötrofil sayısı artarken, inaktif hastalar ve kontrollerden farklı olarak serum lenfosit sayısı azalmaktaydı. Kontrol, aktif olmayan ve aktif ÜK hastalarının ortalama NLR'ları sirasiyla $2.26 \pm 1.75,3.18 \pm 2.10$ ve $4.94 \pm 4.24$ idi. Aktif hastaların serum NLR'ları, inaktif ÜK ve kontrol grubuna göre anlamlı derecede yüksekti $(\mathrm{p}<0.01)$. Yine aktif hastalık grubunda PLR değerleri remisyon ve kontrol grubuna göre istatiksel olarak anlamlı derecede yüksekti $(225.79 \pm 151.73$, $183.95 \pm 88.00,124.98 \pm 53.53$ sirasiyla) $(\mathrm{p}<0.01)$.

Klinik aktiviteye göre NLR ve PLR değişkenlerinin hangi gruplar arasında farkllılk gösterdiğini belirlemek için tek yönlü varyans analizi (ANOVA) sonrası post-hoc test sonuçları Tablo 3'te gösterilmiștir. Kontrol grubu ile hem remis- yon hem de aktif hastalık grupları arasında, PLR değisskeni açısından istatiksel olarak anlamlı farklılık vardı $(\mathrm{p}=0.01$ ve $<0.001$, sirasıyla). Remisyon ve aktif hastalık grupları arasinda PLR açısından farklılık saptanmadı $(\mathrm{p}=0.25)$. NLR açısindan kontrol grubu ile remisyon grubu arasında fark gözlenmezken $(\mathrm{p}=0.10)$, kontrol grubu ile aktif hastalık grubu arasında anlamlı farklılık gözlendi ( $p<0.001)$. Remisyon ve aktif hastalık grupları arasında NLR açısından anlamlı farklılık gözlendi ( $\mathrm{p}=0.03)$.

Yapılan korelasyon analizinde KAI ile pozitif korelasyon saptanan değerler; WBC sayısı ( $\mathrm{rs}=0.39, \mathrm{p}=0.00)$, PLR ( $\mathrm{r} s=0.43$, $\mathrm{p}=0.00), \operatorname{NLR}(\mathrm{rs}=0.46, \mathrm{p}=0.00), \mathrm{CRP}(\mathrm{rs}=0.62, \mathrm{p}=0.00), \mathrm{ESR}$ (rs $=0.65, \mathrm{p}=0.00)$ şeklindeydi.

KAI'ni öngörebilme açısından WBC, ESR, CRP, NLR ve PLR değerlerine ROC analizi uygulandı (Figür 1). En yüksek AUC değerleri sirasiyla ESR $(0.84 \pm 0.05, \mathrm{p}<0.01), \mathrm{CRP}(0.82 \pm 0.06$, $\mathrm{p}<0.01)$, NLR $(0.80 \pm 0.05, \mathrm{p}<0.01)$, PLR $(0.74 \pm 0.06, \mathrm{p}$ $<0.01)$ ve $\mathrm{WBC}(0.74 \pm 0.06, \mathrm{p}<0.01)$ şeklindeydi. NLR ve PLR için kesme değerleri, sırasıyla, 2.10 (\%90 sensitivite, $\% 45$ spesifite) ve 152.13 (\%70 sensitivite, \%33 spesifite) olarak saptandı. 
Tablo 3. Değişkenlerin hangi gruplar arasında farklılık gösterdiğini belirlemek için tek yönlü varyans analizi (ANOVA) sonrası post-hoc test sonuçları (Dunnett T3)

\begin{tabular}{|c|c|c|c|c|c|}
\hline \multirow[t]{2}{*}{ Değişken } & \multirow[t]{2}{*}{ (I) KAİ Grup } & \multirow[t]{2}{*}{ (J) KAİ Grup } & \multirow[t]{2}{*}{$\mathbf{p}$} & \multicolumn{2}{|c|}{ \%95 Güven Aralığı } \\
\hline & & & & Alt Sinir & Üst Sinır \\
\hline \multirow{2}{*}{ PLR } & Kontrol grubu & $\begin{array}{l}\text { Remisyon grubu } \\
\text { Aktif hastalık grubu }\end{array}$ & $\begin{array}{c}0.01 \\
<0.001\end{array}$ & $\begin{array}{l}-100.23 \\
-151.70\end{array}$ & $\begin{array}{l}-17.71 \\
-49.90\end{array}$ \\
\hline & Remisyon grubu & $\begin{array}{c}\text { Kontrol grubu } \\
\text { Aktif hastalık grubu }\end{array}$ & $\begin{array}{l}0.01 \\
0.25\end{array}$ & $\begin{array}{c}17.71 \\
-101.93\end{array}$ & $\begin{array}{l}100.23 \\
18.26\end{array}$ \\
\hline \multirow{2}{*}{ NLR } & Kontrol grubu & $\begin{array}{l}\text { Remisyon grubu } \\
\text { Aktif hastalık grubu }\end{array}$ & $\begin{array}{l}0.10 \\
<0.001\end{array}$ & $\begin{array}{l}-1.97 \\
-4.12\end{array}$ & $\begin{array}{c}0.13 \\
-1.22\end{array}$ \\
\hline & Remisyon grubu & $\begin{array}{c}\text { Kontrol grubu } \\
\text { Aktif hastalık grubu }\end{array}$ & $\begin{array}{l}0.10 \\
0.03\end{array}$ & $\begin{array}{l}-0.13 \\
-3.34\end{array}$ & $\begin{array}{c}1.97 \\
-0.16\end{array}$ \\
\hline
\end{tabular}

KAI: Klinik aktivite indeksi, NLR: Nötrofil lenfosit oranı, PLR: Platelet lenfosit oranı.

Tablo 4. EAI'ine göre inflamasyon belirteçlerinin gruplar arasında karşılaştırılması

$\begin{array}{lcccc}\text { Değişkenler } & \text { Çalışma Grubu } & \text { İnaktif Hastalık } & \text { Aktif Hastalık } & \text { p } \\ \text { WBC } & 7277.86 \pm 1717.22 & 8164.44 \pm 2553.33 & 9555 \pm 3341.69 & <0.01 \\ \text { ESR } & 4.89 \pm 2.27 & 20.62 \pm 13.08 & 26.76 \pm 18.56 & <0.01 \\ \text { CRP } & 4.47 \pm 2.48 & 15.21 \pm 19.47 & 37.20 \pm 41.60 & <0.01 \\ \text { NLR } & 2.26 \pm 1.75 & 2.77 \pm 1.38 & 4.92 \pm 4.14 & <0.01 \\ \text { PLR } & 124.98 \pm 53.53 & 171.71 \pm 70.52 & 226.35 \pm 148.99 & <0.01\end{array}$

EAI: Endoskopik aktivite indeksi, WBC: Lökosit sayısı, ESR: Eritrosit sedimantasyon hızı, CRP: C reaktif protein, NLR: Nötrofil lenfosit oranı, PLR: Platelet lenfosit oranı.

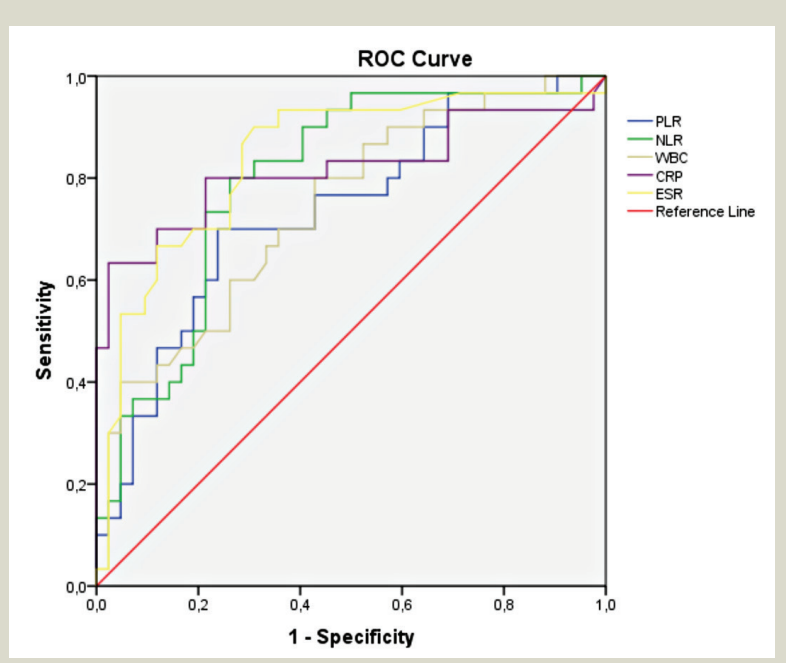

Figür 1. Hastalık klinik aktivitesini öngörmede inflamasyon belirteçlerinin karşılaştırılması.

PLR: Platelet lenfosit oranı, NLR: Nötrofil lenfosit oranı, WBC: Lökosit sayısı, CRP: C reaktif protein, ESR: Eritrosit sedimantasyon hızı.

EAI'lerine göre hasta grupları arasındaki inflamasyon belirteçlerinin karşılaştırılması Tablo 4'te verilmiştir. Aktif gruptaki ortalama WBC, CRP ve ESR değerleri remisyon grubu ve kontrol grubuna göre anlamlı derecede yüksekti ( $p<0.01$ ). Kontrol, aktif olmayan ve aktif ÜK hastalarının ortalama
NLR'ları sirasıly $2.26 \pm 1.75,2.77 \pm 1.38$ ve $4.92 \pm 4.14$ idi. Aktif hastaların serum NLR değerleri, inaktif ÜK ve kontrol grubuna göre anlamlı derecede yüksekti ( $p<0.01$ ). Yine endoskopik aktif hastalık grubunda PLR değerleri remisyon ve kontrol grubuna göre istatiksel olarak anlamlı derecede yüksekti $(226.35 \pm 148.99,171.71 \pm 70.52,124.98 \pm 53.53$ sirasiyla) $(\mathrm{p}<0.01)$.

Endoskopik aktivitelerine göre NLR ve PLR değişkenlerinin hangi gruplar arasında farklılık gösterdiğini belirlemek için tek yönlü varyans analizi (ANOVA) sonrası post-hoc test sonuçları Tablo 5'te gösterilmiştir. Kontrol grubu ile hem remisyon hem de aktif hastalık grupları arasında, PLR değişkeni açısından istatiksel olarak anlamlı farklılık vardı $(p=0.01$ ve $p$ $<0.001$, siasıyla). Remisyon ve aktif hastalık grupları arasında PLR açısından farklılık saptanmadı ( $\mathrm{p}=0.05)$. NLR açısından kontrol grubu ile remisyon grubu arasında fark gözlenmezken ( $p=0.38)$, kontrol grubu ile aktif hastalık grubu arasında anlamlı farklılık gözlendi ( $p<0.001$ ). Remisyon ve aktif hastalık grupları arasında da NLR açısından, anlamlı farklılık gözlendi ( $\mathrm{p}<0.001)$.

Yapılan korelasyon analizinde EAİ ile pozitif korelasyon saptanan değerler: WBC sayısı ( $r s=0.41, \mathrm{p}=0.00$ ), PLR ( $r s=0.45$, $\mathrm{p}=0.00), \mathrm{NLR}(\mathrm{rs}=0.48, \mathrm{p}=0.00), \mathrm{CRP}(\mathrm{r}=0.55, \mathrm{p}=0.00), \mathrm{ESR}$ ( $r s=0.65, \mathrm{p}=0.00)$ şeklindeydi. 
Tablo 5. Değişkenlerin hangi gruplar arasında farklılık gösterdiğini belirlemek için tek yönlü varyans analizi (ANOVA) sonrası post-hoc test sonuçları (Dunnett T3)

\begin{tabular}{|c|c|c|c|c|c|}
\hline \multirow[t]{2}{*}{ Değişken } & \multirow[t]{2}{*}{ (I) Klinik EAİ Grup } & \multirow[t]{2}{*}{ (J) Klinik EAİ Grup } & \multirow[t]{2}{*}{$\mathbf{p}$} & \multicolumn{2}{|c|}{ \%95 Güven Aralı̆̆ı } \\
\hline & & & & Alt Sinir & Üst Sinır \\
\hline \multirow{2}{*}{ PLR } & Kontrol grubu & $\begin{array}{l}\text { Remisyon grubu } \\
\text { Aktif hastalık grubu }\end{array}$ & $\begin{array}{c}0.01 \\
<0.001\end{array}$ & $\begin{array}{l}-84.85 \\
-148.96\end{array}$ & $\begin{array}{l}-8.59 \\
-53.77\end{array}$ \\
\hline & Remisyon grubu & $\begin{array}{c}\text { Kontrol grubu } \\
\text { Aktif hastalık grubu }\end{array}$ & $\begin{array}{l}0.01 \\
0.05\end{array}$ & $\begin{array}{c}8.59 \\
-109.85\end{array}$ & $\begin{array}{l}84.85 \\
0.56\end{array}$ \\
\hline \multirow{2}{*}{ NLR } & Kontrol grubu & $\begin{array}{l}\text { Remisyon grubu } \\
\text { Aktif hastalık grubu }\end{array}$ & $\begin{array}{c}0.38 \\
<0.001\end{array}$ & $\begin{array}{l}-1.37 \\
-4.01\end{array}$ & $\begin{array}{l}0.35 \\
-1.30\end{array}$ \\
\hline & Remisyon grubu & $\begin{array}{c}\text { Kontrol grubu } \\
\text { Aktif hastalık grubu }\end{array}$ & $\begin{array}{c}0.38 \\
<0.001\end{array}$ & $\begin{array}{l}-0.35 \\
-3.53\end{array}$ & $\begin{array}{c}1.37 \\
-0.75\end{array}$ \\
\hline
\end{tabular}

EAI: Endoskopik aktivite indeksi, NLR: Nötrofil lenfosit oranı, PLR: Platelet lenfosit oranı.

\begin{tabular}{lccccc}
\multicolumn{5}{l}{ Tablo 6. Anatomik tutulum bölgelerine göre değişkenlerin } & gruplar arasında karşılaştırılması \\
& CRP & WBC & ESR & PLR & NLR \\
Chi-Square & 3.012 & 2.266 & 2.687 & 4.569 & 4.529 \\
df & 2 & 2 & 2 & 2 & 2 \\
p & 0.22 & 0.32 & 0.26 & 0.10 & 0.10
\end{tabular}

WBC: Lökosit sayısı, ESR: Eritrosit sedimantasyon hızı, CRP: C reaktif protein, NLR: Nötrofil lenfosit oranı, PLR: Platelet lenfosit oranı.

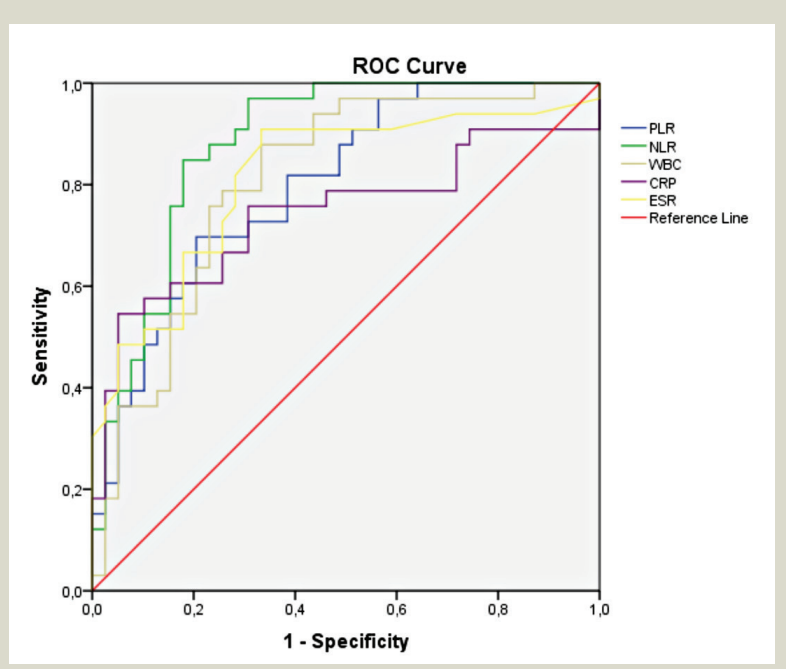

Figür 2. Hastalık endoskopik aktivitesini öngörmede inflamasyon belirteçlerinin karşılaştırılması.

PLR: Platelet lenfosit oranı, NLR: Nötrofil lenfosit oranı, WBC: Lökosit sayısı, CRP: C reaktif protein, ESR: Eritrosit sedimantasyon hızı.

EAI'ini öngörebilme açısından WBC, ESR, CRP, NLR ve PLR değerlerine ROC analizi uygulandı (Figür 2). En yüksek AUC değerleri sirasiyla NLR $(0.88 \pm 0.04, \mathrm{p}<0.01)$, ESR $(0.82 \pm 0.05$, $\mathrm{p}<0.01)$, WBC $(0.81 \pm 0.05, \mathrm{p}<0.01)$, PLR $(0.80 \pm 0.05, \mathrm{p}$ $<0.01)$ ve $\mathrm{CRP}(0.74 \pm 0.06, \mathrm{p}<0.01)$ şeklindeydi. NLR ve PLR için kesme değerleri sırasılyla 2.09 (\%97 sensitivite, \%39 spesifite) ve 151.72 (\%73 sensitivite, \%31 spesifite) olarak saptandi.
Inflamatuvar belirteçlerin ÜK hastalarında, anatomik dağılıma göre gruplar arasında, istatistiksel olarak farklı olmadığı görüldü. WBC, CRP, ESR, NLR ve PLR için değerler sirasıyla $\mathrm{p}=0.32$, $\mathrm{p}=0.22, \mathrm{p}=0.26, \mathrm{p}=0.10$ ve $\mathrm{p}=0.10$ olarak saptand (Tablo 6).

\section{TARTIŞMA}

ÜK klinik olarak remisyon ve alevlenme dönemleriyle seyreden kronik inflamatuvar bir hastalıktır. ÜK'in hastalık aktivitesine ve ciddiyetine göre sinıflandırılması klinik uygulamada önemlidir, çünkü hastanın yönetimi buna göre belirlenir. Bu amaçla çok sayıda klinik ve endoskopik aktivite indeksleri geliştirilmiştir (12-14). Bizim çalışmamızda NLR ile PLR degerlerinin, ÜK hastalarında hem klinik aktivasyon hem de endoskopik aktivasyon indeksleri ile ilişkili olduğu ortaya konuldu. Ortaya koyduğumuz bu ilişki anatomik dağılımdan bağımsızdı.

Hastalığın ciddiyetini öngörebilecek ideal bir serum belirteci olmamasına rağmen, WBC, CRP ve ESR, ÜK aktivitesini belirlemek için klinik uygulamalarda sıklıkla kullanılsalar da intestinal inflamasyon için düşük duyarlılıkları ve özgüllükleri nedeniyle hastalık aktivitesini yeterince yansıtamamaktadır$\operatorname{lar}(15,16)$. Önceki çalışmalar, CRP ve ESR'lerin hastalık aktivitesini belirlemek için WBC'den daha anlamlı parametreler olduğunu göstermiştir (15-18). Osada ve arkadaşları, CRP, ESR ve WBC sayımlarının endoskopik ve histolojik skorların toplamıla korele olduğunu ayrıca, CRP ve ESR'nin distal kolon tutulumu ile uyumlu olmadığını ancak proksimal kolon 
tutulumunun aktivitesi ile iyi korele olduğunu bildirmişlerdir (15). Bizim çalışmamız da yukarıdaki üç belirteçin, literatür ile uyumlu olarak hem KAI hem de EAI ile güçlü pozitif bağıntılarının olduğunu ve bunun lokalizasyondan bağımsız olduğunu ortaya koymuştur. KAI'ini öngörebilme açısından WBC, ESR, CRP için en yüksek AUC değerleri sırasıyla ESR (\%84, p <0.01), CRP (\%82, p <0.01) ve WBC (\%74, p <0.01) şeklindeydi. EAI'ini öngörebilme açısından WBC, ESR, CRP için en yüksek AUC değerleri sırasıyla ESR (\%82, p <0.01), WBC (\%81, p <0.01) ve CRP (\%74, p <0.01) şeklindeydi. Bu belirteçlerin klinik gözlem, diğer laboratuvar parametreleri ve kolonoskopi ile birlikte kullanılması, ÜK aktivitesinin belirlenmesinde önemini artıracaktır.

Kan NLR'ı; akut pankreatit, koroner arter hastalı̆ı ve bazı malignitelerin sonuçlarını belirlemek için kullanılan, basit ve ucuz bir sistemik inflamasyon belirtecidir (6-8). Lenfoplazmositer infiltrasyon ile karakterize kronik yapısının ötesinde, ülseratif kolitin alevlenme dönemleri nötrofil aracılı epitel hasarı ile ilişkilidir. Kript apseleri ve kriptit, mukozal kriptlere nötrofil infiltrasyonu ile karakterize edilir $(8,17)$. NLR'nin klinik olarak aktif kolitte artış gösterdiği belgelenmiştir $(8,9,18)$. Son zamanlarda, yapılmış çalışmalarda, KAl'ini öngörmek için NLR'nin duyarlılığı sırasıyla \%61.2 ve \%81.8 bulunmuştur $(9,20)$. Çalışmamızda NLR için kesme değeri $2 \cdot 10$ (\%90 sensitivite, \%45 spesifite) (AUC 0.80; p <0.01) olarak tespit edildi. Literatürde EAI ile NLR'ın karşılaştırıldığı çok fazla çalışma yoktur. Akpınar ve ark. yaptıkları çalışmada, endoskopik aktif hastalığı öngörmek için NLR'nin duyarlılığını \%76 (AUC 0.718, $\mathrm{p}=0.003$ ) olarak tespit etmişlerdir. Bu çalışmada EAI'ini öngörmede NLR için kesme değeri 2.09 (\%97 sensitivite, \%39 spesifite) (AUC 0.88, p <0.01) olarak tespit edildi.

\section{KAYNAKLAR}

1. Lamb CA, Kennedy NA, Raine T, et al. British Society of Gastroenterology consensus guidelines on the management of inflammatory bowe disease in adults. Gut 2019;68(Suppl 3):sl-s106.

2. Caprilli R, Viscido A, Latella G. Current management of severe ulcerative colitis. Nat Clin Pract Gastroenterol Hepatol 2007;4:92-101.

3. Lok KH, Ng CH, Hung HG, Li KF, Li KK, Szeto ML. Correlation of serum biomarkers with clinical severity and mucosal inflammation in Chinese ulcerative colitis patients. J Dig Dis 2008;9:219-24.

4. Hassan EA, Ramadan HK, Ismael AA, et al. Noninvasive biomarkers as surrogate predictors of clinical and endoscopic remission after infliximab induction in patients with refractory ulcerative colitis. Saudi J Gastroenterol 2017;23:238-45.

5. Vermeire S, Van Assche G, Rutgeerts P. Laboratory markers in IBD: Useful, magic, or unnecessary toys? Gut 2006;55:426-31

6. Zahorec R. Ratio of neutrophil to lymphocyte counts - rapid and simple parameter of systemic inflammation and stress incritically ill. Bratisl Lek Listy 2001;102:5-14.

7. Yodying H, Matsuda A, Miyashita M, et al. Prognostic significance of neutrophil-to-lymphocyte ratio and platelet-to-lymphocyte ratio in oncologic outcomes of esophageal cancer: A systematic review and meta-analysis. Ann Surg Oncol 2016;23:646-54.
NLR'ye benzer şekilde, PLR de sistemik inflamasyonun dolaylı bir göstergesidir. Trombosit sayısı, akut inflamasyonda salg1lanan sitokinlerden etkilenebilir ve trombositoz, akut inflamasyonun yaygın bir özelliğidir (21). Bu parametre prognozu tahmin etmek için bazı kanser türlerinde ve diğer inflamatuvar durumlarda geniş çapta araştırılmıştır $(7,8)$. Ancak ÜK'te PLR ile ilgili çalışmalar çok azdır. Akpınar ve ark. yaptıkları çalışmada, PLR için optimal kesim noktasını sırasıyla \%77.9 duyarlllk ve \%74 özgüllük ile 138.6 olarak (AUC 0.748, p <0.001) tespit etmişlerdir (8). Yaptığımız çalışmada EAl'ini ön görmede PLR için kesme değeri 151.72 (\%73 sensitivite, \%31 spesifite) olarak saptandı (AUC 0.80, p <0.01). Yine çalışmamızda KAI'ini öngörmede PLR için kesme değeri 152.13 (\%70 sensitivite, $\% 33$ spesifite) (AUC 0.74, p <0.01) olarak saptand1.

Çalışmamız çeşitli kısıtllılklar içermektedir. Bunların başında retrospektif karakterde olması ve tek merkez sonuçlarını içeriyor olmasıdır. Ayrıca çalışılan parametreler hastalığa özgü olmayıp çok sayıda faktörün (enfeksiyon, ilaç, inflamasyon vs.) sonuçları etkileyebileceği de unutulmamalıdır.

Sonuç olarak, çalışmamız aktif ÜK hastalarında NLR ve PLR seviyelerinin anlamlı şekilde arttı̆̆ını ve bunun klinik, endoskopik ve laboratuvar endeksleri ile korele olduğunu göstermiștir. Bu inflamatuvar belirteçler tek başına ya da birlikte hastalık aktivitesini tahmin edebilir. Verilerimizin daha geniş ve çok merkezli çalışmalar ile desteklenmesi gerekmektedir. Tüm bunların neticesinde ucuz ve kolay uygulanabilir bir test olarak invaziv olmayan bu belirteçlerin ÜK'teki hastalık aktivitesinin hızlı bir şekilde değerlendirilmesi için değerli bir araç olabileceklerini düşünüyoruz.

\section{"Tüm yazarlar herhangi bir çıkar çatışması olmadığını kabul ederler."}

8. Akpinar MY, Ozin YO, Kaplan M, et al. Platelet to lymphocyte ratio and neutrophil to lymphocyte ratio predict mucosal disease severity in ulcerative colitis. J Med Biochem 2018;37:155-62.

9. Demir AK, Demirtas A, Kaya SU, et al. The relationship between the neutrophile lymphocyte ratio and disease activity in patients with ulcerative colitis. Kaohsiung J Med Sci2015;31:585-90.

10. Satsangi J, Silverberg MS, Vermeire S, Colombel JF. The Montreal classification of inflammatory bowel disease: controversies, consensus, and implications. Gut 2006;55:749-53

11. Feagan BG, Greenberg GR, Wild G, et al. Treatment of ulcerative colitis with a humanized antibody to the alpha4beta7 integrin. N Engl J Med 2005;352:2499-507

12. Lee JS, Kim ES, Moon W. Chronological review of endoscopic indices in inflammatory bowel disease. Clin Endosc 2019;52:129-36.

13. Rosenberg L, Lawlor GO, Zenlea T, et al. Predictors of endoscopic onflammation in patients with ulcerative colitis in clinical remission. Inflamm Bowel Dis 2013;19:779-84

14. D'Haens G, Sandborn WJ, Feagan BG, et al. A review of activity indices and efficacy end points for clinical trials of medical therapy in adults with ulcerative colitis. Gastroenterology 2007;132:763-86. 
15. Osada T, Ohkusa T, Okayasu I, et al. Correlations among total colonoscopic findings, clinical symptoms, and laboratory markers in ulcerative colitis. J Gastroenterol Hepatol 2008;23:S262-7.

16. Yoon JY, Park SJ, Hong SP, et al. Correlations of C-reactive protein levels and erythrocyte sedimentation rates with endoscopic activity indices in patients with ulcerative colitis. Dig Dis Sci 2014;59:829-37.

17. Karoui S, Laz S, Serghini M, et al. Correlation of C-reactive protein with clinical and endoscopic activity in patients with ulcerative colitis. Dig Dis Sci 2011;56:1801-5.

18. Celikbilek M, Dogan S, Ozbakir O, et al. Neutrophil-lymphocyte ratio as a predictor of disease severity in ulcerative colitis. J Clin Lab Anal 2013;27:72-6.
19. Gewirtz AT, Liu Y, Sitaraman SV, Madara JL. Intestinal epithelial pathobiology: Past, present and future. Best Pract Res Clin Gastroenterol 2002;16:851-67.

20. Posul E, Yilmaz B, Aktas G, Kurt M. Does neutrophil-tolymphocyte ratio predict active ulcerative colitis? Wiev Klin Wochenschr 2015;127:2625 .

21. Voudoukis E, Karmiris K, Koutroubakis IE. Multipotent role of platelets in inflammatory bowel diseases: a clinical approach. World J Gastroenterol 2014:20:3180-90. 